\title{
EFFECT OF NPK AND SEA FORCE EXTRACT ON GROWTH CHARACTERS AND TOTAL FLAVONOID CONTENT OF Calendula officinalis
}

\author{
Sawsan M.S. Ali Kanimarani ${ }^{*}$, AlaAdin Mohammed Naqishbandi ${ }^{*}$ and Sabeha Salahaddin Mustafa* \\ *Dept. of Horticulture, College of Agriculture, University of Salahaddin, Kurdistan Region-Iraq \\ ** Dept. of pharmacognosy, College of pharmacy, Hawler Medical University, Kurdistan Region-Iraq
}

(Received: December 12, 2018; Accepted for Publication: March 6, 2019)

\begin{abstract}
Marigold (Calendula officinalis) is an important medicinal and ornamental plant, this study conducted in the Lethalhouse, Grdarasha field, Agriculture College, Salahaddin University through January $5^{\text {th }}$ to April

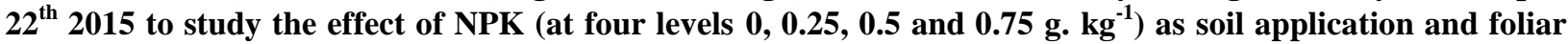
spray of sea force (at the concentrations of $0,1,2$ and $3 \mathrm{mg}^{-\mathrm{L}^{-1}}$ ) on some Calendula afficinalis vegetative growth and flower features and total flavonoid content in the leaves and flowers. The best result of plant height $(64.89 \mathrm{~cm})$ was obtained from NPK $0.75 \mathrm{~g} . \mathrm{kg}^{-1}$ and the highest number of the leaves and flowers $(195.96$ and 19.18 respectively) were obtained from NPK $0.50 \mathrm{~g} . \mathrm{kg}^{-1}$. However, the highest values of plant hight and number of flowers were recorded from $1 \mathrm{mg} . \mathrm{L}^{-1}$ sea force extract. The interaction treatment of $0.50 \mathrm{~g} . \mathrm{kg}^{-1}$ NPK and $2 \mathrm{mg} . \mathrm{L}^{-1}$ Sea force gave the highest plant, and $0.75 \mathrm{~g} . \mathrm{kg}^{-1} \mathrm{NPK}$ with $1 \mathrm{mg} . \mathrm{L}^{-1}$ sea force interaction gave the greatest number of flowers per plant (20.38). Total flavonoid content in leaves extracts is directly proportional to NPK concentrations. The maximum flavonoid contents were $21.320 \pm 0.010$ and $21.915 \pm$ $0.071 \mathrm{mg} . \mathrm{kg}^{-1}$ in the leaves and flowers extracts treated with $0.25 \mathrm{~g} . \mathrm{kg}^{-1} \mathrm{NPK}, 3 \mathrm{mg} . \mathrm{L}^{-1}$ sea force and $0.75 \mathrm{~g} . \mathrm{kg}^{-}$ ${ }^{1} \mathrm{NPK}, 3 \mathrm{mg} . \mathrm{L}^{-1}$ sea force respectively, the flowers are with higher amounts of total flavonoid content.
\end{abstract}

KEY WARD: NPK, sea force, Calendula officinalis growth, total flavonoid content

\section{INTRODUCTION}

M arigold (Calendula officinalis) belongs to Asteraceae family. The plant is a winter annual, seldom biennial. It grows to between 30 and $50 \mathrm{~cm}$ high, and has about $20 \mathrm{~cm}$ long tap root and numerous thin secondary roots. The stem is erect, angular and downy and branched from the base up or higher. The alternate leaves are almost spatulas at the base, it has quite long flowering period, resistant to cold weather and it possible to the flowers from spring to winter (Muley et al., 2009). Flowering of marigold plants under short photo-periods, however there is a long flowering period too. The plants can be used in the home garden and in landscaping. It is one of the best plants for rock gardens, borders, flower beds and balcony plantings (Golestani et al., 2013). (Calendula officinalis ) besides being an ornamental plant, is a medicinal plant used in pharmaceutical and cosmetic industries since ancient times. Today, as well as folk medicine, active ingredients are widely used medicines and pharmaceuticals, especially the flowers are quite rich in various active ingredients ( Caliskan and
Kurt, 2018). Chemical studies revealed various essential oils, carotenoids, flavonoids, terpenoids, coumarins, quinines, carbohydrate, oil, amino acid, and various minor compounds for pot marigold plants. It is potentially an important medicinal plant, because it has many pharmacological activities (HIV, anti-cancer, antiinflammatory, hepatoprotective, spasmolytic and spasmogenic. (Muley et al., 2009 and Mohammad and Kashani, 2012).

Chemical fertilization is primarily tried to stimulate growth or to increase the medicinally active ingredients in plant extracts (Naguib, 2011). The photosynthesis and the accumulation of carotenoids pigments in flowers of marigold plants have been stimulated with the mineral fertilizer treatments (Marta et al., 2012). Plant nutrition is one of the most important factors affecting quantity and quality of secondary metabolites in plants. In order to meet the ever increasing demand of medicinal plants need to be identified the best fertilizer application strategies. It is apparent that essential oil content enhance with increasing plant age to reach the maximum values at post flowering stage. The yield of plant 
fresh herb, the essential oil content and its composition can be influenced by growth stages, ecological and climatic conditions. Several attempts have been made to increase yield potential of medicinal plants Janmohammadi et al., (2014). Seaweed extracts are well-known biostimulants. They are characterized by high efficiency in plants cultivation what was proved by many papers, besides they are environmentally friendly due to biological origin of material. Therefore, algal extracts can constitute an alternative to synthetic plant stimulants, the application of which very often causes environmental pollution, and support to traditional fertilizers (Tuhy et al.,2013). Seaweed formulations basing on algal extracts are rich in phytohormones (gibberelins, auxins, cytikinins), amino acids and fatty acids which are responsible for plant growth, development and resistance to pathogens, and also contain macro and micro elements (Co, B, Mo, Zn, Cu [Jensen, 2004; Abdulrahman, 2013 and Tuhy et al., 2013).].

Paim, et al. (2009) compared between organic plant composed (60 ton.ha $\left.{ }^{-1}\right)$ and chemical fertilizer represented by NPK $(0,80,120$ and 80 kg.ha ${ }^{-1}$ ) treated on Calendula officinalis, The results suggested that the organic plant composed treatment was able to increase the vegetative development of the medicinal species calendula during the first 45 days of development. After 95 days both treatments of organic and chemical fertilizers produced similar results to each other with regard to the vegetative development of the plant, demonstrating that for this plant cultivation treatments such as the addition of organic and chemical fertiliser improve the development of the plant, when compared to the control without fertiliser. In relation to the quantification of flavonoids, it can be seen that the NPK treatment raised the quantity of total flavonoids by around $10 \%$ when compared to organic plant composed treatments, it is supposed that the nitrogen present in NPK may be related to this phenomenon, given that this nutrient participates in the flavonoid biosynthetic pathway. Hashemabadi et al. (2012) studied different levels $\left(0,100,200\right.$ and $300 \mathrm{~kg}^{2} \mathrm{ha}^{-}$ $\left.{ }^{1}\right)$ of potassium sulfate (K2SO4) fertilizer on Calendula officinalis yield and essential oils quantitative, the results showed that the plant height, the number of flowers, flowers dry weight, potassium content of aerial part, flower essential oil and carotenoids content in petals were significantly increased. Sajid and Amin (2014) studied the impact of various $\mathrm{N}, \mathrm{P}, \mathrm{K}$ combinations (Control, Nitrogen $(\mathrm{N})$, Phosphorus $(\mathrm{P})$, Potash $(\mathrm{K}), \mathrm{N}+\mathrm{P}, \mathrm{N}+\mathrm{K}, \mathrm{P}+\mathrm{K}$ and $\mathrm{N}+\mathrm{P}+\mathrm{K})$ on Chrysanthemum morifolium) growth, the $(\mathrm{N}+\mathrm{P}+\mathrm{K})$ combination was significantly better with plant height $(63.9 \mathrm{~cm})$, maximum leaf area (131.6 cm2), less days (116) to flower, more number of flowers (32), maximum blooming period (38 days), larger flower size $(6.3 \mathrm{~cm})$ and flower fresh weight $(4.4 \mathrm{~g})$. Untreated plants had least plant height $(46.5 \mathrm{~cm})$, number of branches (7) per plant, number of leaves (47) per plant, leaf area $(94.2 \mathrm{~cm} 2)$, number of flowers (15) per plant, blooming period (35 days), flower size $(4.5 \mathrm{~cm})$ and fresh weight $(3.3 \mathrm{~g})$. Treatment of plants with $(\mathrm{N}+\mathrm{P}+\mathrm{K})$ combination alone gave flowering after 116 days from planting in $7 \mathrm{~cm}$ pots and produced flowers earlier than the control. Rajput (2015) observed that the treatment of (Nitrogen $80 \mathrm{~kg} \cdot \mathrm{ha}^{-1}$ + Phosphorus $40 \mathrm{~kg} \cdot \mathrm{ha}^{-1}$ ) was showed better results of plant height, plant spread, number of leaves per plant, number of primary branches per plant, number of secondary branches per plant, stem diameter, the early bud appearance, the maximum number of flowers per plants, flowers diameter, individual flower weight, flower yield per plant and flower yield . plot $^{-1}$, the maximum weight of seed . flower $^{-1}, 100$ seed weight and seed yield plant ${ }^{-1}$, however the minimum number of flowers. plant ${ }^{-1}$, flower diameter, individual flower weight, flower yield . plant ${ }^{-1}$ and flower yield . plot $^{-1}$ were recorded in the control. Ahmed et al. (2017) investigated four levels of $\mathrm{N}(0,60$, 90 and $120 \mathrm{~kg}$ ha -1$), \mathrm{P}(0,30,40$ and $50 \mathrm{~kg}$ ha -1 ) and $\mathrm{K}(0,60,90$ and $120 \mathrm{~kg}$ ha -1$)$ with a dose of $2 \mathrm{~kg} \mathrm{~B}$ and $4 \mathrm{~kg} \mathrm{Zn}$ ha -1 . Flower yield and yield attributes of marigold significantly increased with NPK fertilizer for three years. The significantly highest flower yield was obtained from $\mathrm{N}, \mathrm{P}$, and $\mathrm{K}$ combination treatment at the levels of 90,40 and $90 \mathrm{~kg} \mathrm{ha}^{-1}$ respectively with dose of $2 \mathrm{Kg} \mathrm{B}$ and $4 \mathrm{~kg} \mathrm{Zn} \mathrm{ha}{ }^{-1}$. Priyadarshini et al.(2018) found that the application of $75 \% \mathrm{~N}$ from Urea and $25 \% \mathrm{~N}$ from vermicompost resulted in significant differences in vegetative characters, plant height, plant spread, number of branches (primary and secondary branches), leaf area, stem diameter, days to $50 \%$ flowering, days to first flower bud appearance, days to first harvest, shelf-life of flower, flowering duration, number of flower per plant, number of harvests, number of flower per $\mathrm{m}^{2}$ and weight (yield) of flower. Plant ${ }^{-1}$. Size of flower (diameter) and 
individual flower weight did not vary significantly among the treatments in this experiment.

Therefore the goal is to investigate effectiveness and efficiency of NPK and sea force fertilizers with their interaction on growth, flowering and total flavonoid content of Calendula officinalis.

\section{MATERIALS AND METHODS}

Lethalhouse experiment accomplished in Grdarasha field, Agriculture College of
Salahaddin University (Latitude North, Longitude East $44.03^{\circ}$ and altitude $436 \mathrm{~m}$ above sea level), through January $5^{\text {th }}$ to April $22^{\text {th }} 2015$ to study the effect of NPK ( at four levels 0, 0.25, 0.5 and 0.75 g. $\mathrm{kg}^{-1}$ ) as soil application and foliar spray of sea force (at the concentrations of $0,1,2$ and $3 \mathrm{mg} .1^{-1}$ ) on Calendula afficinalis. Some of soil properties showing in table (1). Monthly averages temperature and humidity were recorded throughout the experiment period shown in table (2).

Table (1): Some chemical and physical characters of the soil

\begin{tabular}{|c|c|}
\hline Properties & Values \\
\hline Sand (\%) & 67.50 \\
\hline Silt (\%) & 12.50 \\
\hline Clay (\%) & 20.00 \\
\hline Soil texture & $\begin{array}{c}\text { sandy loem to } \\
\text { clay loem }\end{array}$ \\
\hline $\mathrm{pH}(\mathrm{pH}$ meter) & 8.3 \\
\hline $\begin{array}{l}\left.\text { Electrical conductivity(dS.m }{ }^{-1}\right) \\
\text { (EC-meter) }\end{array}$ & 0.4 \\
\hline Organic matter\% & 0.2 \\
\hline $\begin{array}{l}\text { Total Nitrogin }(\mathrm{g} / \mathrm{Kg}) \\
\text { (kjeldaahl method) }\end{array}$ & 0.31 \\
\hline$P(g / K g)$ (Olsen method) & 3.20 \\
\hline $\begin{array}{c}\mathrm{K}(\mathrm{g} / \mathrm{Kg}) \text { (Flame photometer } \\
\text { method) }\end{array}$ & 1.40 \\
\hline
\end{tabular}

*Laboratory of Soil department, college of Agriculture, Salahaddin University.

\subsection{Plant material}

The Calendula officialis local seed were sown in the soil, then the seedlings at the growth stage of three true leaves were transplanted to polyethylene bags $(18 \mathrm{~cm}$ in diameter $* 22 \mathrm{~cm}$ in height and five $\mathrm{kg}$ in weight). The irrigation was done with tap water if necessary.

Table (2): Maximum and minimum air temperatures and humidity throughout the experiment period.

\begin{tabular}{cccc}
\hline Year & Month & Air temperature $\left({ }^{\circ} \mathbf{C}\right)$ & Relative humidity (\%) \\
\hline \multirow{2}{2015}{} & January & 8.12 & 71.90 \\
\cline { 2 - 4 } & February & 10.61 & 67.84 \\
\cline { 2 - 4 } & March & 11.81 & 63.84 \\
\cline { 2 - 4 } & April & 19.44 & 49.43 \\
\cline { 2 - 4 } & May & 24.73 & 25.64 \\
\hline
\end{tabular}

*Agriculture research center, Ministry of Agriculture, Erbil, Kurdistan region, Iraq

\subsection{NPK treatment}

NPK fertilizer(20:20:20) was added to the soil as a powder at four levels $(0,0.25,0.5$ and $0.75 \mathrm{~g}$. $\left.\mathrm{kg}^{-1}\right)$.

\subsection{Sea force extract treatment}

Sea force extract solution is organic fertilizer prepared from sea algae extracts supplemented with microelements $(2.03 \% \mathrm{~B}, 4.81 \% \mathrm{MgO}$, $3.91 \% \mathrm{~S}, 0.23 \% \mathrm{Mo}$ and $9.78 \% \mathrm{SO}_{3}$, contain $21.15 \%$ organic matter. Sea force solution added 
to the seedlings as foliar spraying at the concentrations of $0,1,2$ and $3 \mathrm{mg}^{-\mathrm{L}^{-1}}$ at two times with 15 days interval.

\subsection{Experimental design and statistical analysis}

Factorial completely randomize design (CRD) with 16 treatments were used, including 4 levels of NPK and 4 concentrations of sea force extract, the treatments were replicated 4 times, each replicate contain of 4 seedlings. Least significant differences test (LSD) at 5\% probability was used for comparisons between means, SAS system was used for all statistical analysis (SAS, 2005).

\subsection{Experimental parameters}

The morphological parameters including; number of leaves.plant ${ }^{-1}$, plant height, number of flower.plant ${ }^{-1}$ and flower diameter (Hasan et al., 2014).

\section{6 Total flavonoid content estimation}

Leaves and flowers of Calendula officinalis obtained from different cultivation conditions were dried, $1 \mathrm{~g}$ of them were extracted separately with $20 \mathrm{ml}$ ethanol $70 \%$ by ultrasonic bath at $40^{\circ} \mathrm{C}$ for $30 \mathrm{~min}$. Crude extracts were filtered and hydroalcoholic extracts under reduced pressure at $60^{\circ} \mathrm{C}$ were evaporated to dryness using rotatory evaporator. The crude extracts obtained from different cultivation conditions were analyzed for total flavonoid content estimation (Cristiane et al., 2009).

Aluminum chloride colorimetric method was used for estimation of total flavonoid content (Hossain et al., 2013). Various concentrations $\left(1.0,0.5,0.25\right.$, and $\left.0.125 \mathrm{mg} . \mathrm{mL}^{-1}\right)$ of standard quercetin in methanol were prepared. $1 \mathrm{~mL}$ quercetin or extract from different cultivation conditions solution was added separately to $4 \mathrm{~mL}$ distilled water in $10 \mathrm{~mL}$ volumetric flask. $0.3 \mathrm{~mL}$ $5 \%$ sodium nitrite was added at the zero time, 0.3 $\mathrm{mL}$ of $10 \% \mathrm{AlCl}_{3}$ was added after $5 \mathrm{~min}$, and 2 $\mathrm{mL}$ of $1 \mathrm{M}$ sodium hydroxide was added to the mixture at $6 \mathrm{~min}$, by the addition of $2.4 \mathrm{~mL}$ distilled water the total volume of the mixture was made up to $10 \mathrm{~mL}$ and mixed thoroughly. Using UV-Visible spectrophotometer absorbance was determined at $510 \mathrm{~nm}$ versus a blank containing all reagents except quercetin. Data reported as mean \pm standard deviation, all the experiments were carried out in triplicates. The average absorbance values obtained at different concentrations of quercetin were used to plot the calibration curve. MS Office Excel 2011 was used for calculation of linear regression equation for a straight line. The regression equation of calibration curve $\left(\mathrm{y}=0.0564 \mathrm{x}-0.0002 ; \mathrm{R}^{2}=\right.$ 0.996), was used for calculation of total flavonoid content and expressed as mg quercetin per gram of dry extract.

\section{RESULTS AND DISCUSSIONS 3.1. Morphological parameters 3.1.1 Effect of NPK:}

Table (3) shows that the levels of NPK caused significant effects on plant height, number of leaves and flowers. The best result of plant height $(64.89 \mathrm{~cm})$ was obtained from $0.75 \mathrm{~g} . \mathrm{kg}^{-1} \mathrm{NPK}$. However, the highest number of leaves (195.96) and flowers (19.18) was observed from $0.50 \mathrm{~g} . \mathrm{kg}$ ${ }^{-1}$ NPK.

Healthy growth of plants and their development can promote by using of fertilizers. Nitrogen enhances plants vegetative growth, phosphorus enhancing seed formation and root development, the potassium helps the stems and straws of plants to be stronger (Sajid and Amin, 2014). Vegetative development in medicinal species is described as one of the factors that can interfere with the amounts of active principles produced by a given species (Paim, et al., 2009). The superiority of NPK might be attributed to the availability of three major nutrients that may led to an enhanced growth as a result of increased cell division, cell enlargement and maximum conversion of photosynthetic products to plant growth. Similar results of higher plant height due to the combined use of $\mathrm{N}, \mathrm{P}$ and $\mathrm{K}$ have been reported by (Verma et al., 2011).

\subsubsection{Effect of sea force extract:}

Plant height, leaves and flowers numbers per plant were significantly affected by sea force foliar application (Table 4). The highest values of Plant height and number of flowers $(61.24 \mathrm{~cm}$ and 16.47 , respectively) were recorded for $1 \mathrm{mg} . \mathrm{L}^{1}$ sea force concentration, while the highest leaves number (180.94) was obtained for control treatment, our results are partially agree with the results of (Hasan et al., 2014) when they were study the effect of organic matter on the growth and flowering of marigold plants. 
Table (3): Effect of NPK on some vegetative growth and flower characteristics of Calendula officinalis.

\begin{tabular}{ccccc}
\hline $\begin{array}{c}\text { NPK } \\
\left(\mathbf{g . k g} \mathbf{~}^{-1}\right)\end{array}$ & $\begin{array}{c}\text { plant height } \\
(\mathbf{c m})\end{array}$ & $\begin{array}{c}\text { Number of } \\
\text { leaves. } \\
\text { plant }^{-1}\end{array}$ & $\begin{array}{c}\text { Number of } \\
\text { flowers. }^{\text {plant }} \mathbf{-}^{-1}\end{array}$ & $\begin{array}{c}\text { Flower } \\
\text { diameter } \\
\mathbf{( c m})\end{array}$ \\
\hline $\mathbf{0}$ & 56.24 & 166.38 & 14.56 & 4.70 \\
\hline $\mathbf{0 . 2 5}$ & 49.35 & 96.81 & 7.19 & 4.32 \\
\hline $\mathbf{0 . 5 0}$ & 62.70 & 195.96 & 19.18 & 4.63 \\
\hline $\mathbf{0 . 7 5}$ & 64.89 & 195.63 & 17.75 & 4.54 \\
\hline L.S.D.<0.05 & $\mathbf{7 . 8 5}$ & $\mathbf{4 0 . 6 8}$ & $\mathbf{4 . 6 5}$ & N.S. \\
\hline
\end{tabular}

Table (4): Effect of sea force on some vegetative growth and flower characteristics of Calendula officinali.

\begin{tabular}{ccccc}
\hline $\begin{array}{c}\text { Sea force } \\
\left(\mathbf{m g} \cdot \mathbf{L}^{-1}\right)\end{array}$ & $\begin{array}{c}\text { plant height } \\
(\mathbf{c m})\end{array}$ & $\begin{array}{c}\text { Number of } \\
\text { leaves. } \\
\text { plant }^{-1}\end{array}$ & $\begin{array}{c}\text { Number of } \\
\text { flowers. } \\
\text { plant }^{-1}\end{array}$ & $\begin{array}{c}\text { Flower } \\
\text { diameter } \\
(\mathbf{c m})\end{array}$ \\
\hline $\mathbf{0}$ & 57.84 & 180.94 & 15.41 & 4.75 \\
\hline $\mathbf{1}$ & 61.24 & 167.83 & 16.47 & 4.59 \\
\hline $\mathbf{2}$ & 56.47 & 166.47 & 13.63 & 4.60 \\
\hline $\mathbf{3}$ & 56.63 & 139.53 & 13.18 & 4.27 \\
\hline L.S.D.<0.05 & $\mathbf{7 . 8 5}$ & $\mathbf{4 0 . 6 8}$ & $\mathbf{4 . 6 5}$ & N.S. \\
\hline
\end{tabular}

\subsubsection{Interaction effects of NPK and sea force:}

The data in the table (5) indicated that the interaction between NPK and sea force caused significant influence in all studied parameters. The highest plant $(69.40 \mathrm{~cm})$ was recorded for 0.50 g.kg ${ }^{-1}$ NPK and $1 \mathrm{mg} .1^{-1}$ sea force interaction treatment. However, the higher number of leaves (222.38) was counted from 0.75 g.kg ${ }^{-1} \mathrm{NPK}$ and 0 $\mathrm{mg} . \mathrm{l}^{-1}$ sea force interaction, and the interaction of the same level of NPK with $1 \mathrm{mg} . \mathrm{l}^{-1}$ sea force gave the highest number of the flowers.plant ${ }^{-1}$ (20.38). The highest flower diameter $(5.20 \mathrm{~cm})$ was obtained from the treatment of 0 g.kg ${ }^{-1} \mathrm{NPK}$ and $2 \mathrm{mg} . \mathrm{L}^{-1}$ sea force extract interaction, this can be due to existence of amino acid compounds and nutrients such as $\mathrm{N}, \mathrm{P}$ and $\mathrm{K}$ which can promote metabolic activities like photosynthesis and absorption and transfer of nutrients from root and leaves (Rafiee et al.,2014). NPK fertilizer is usually used to increase the growth of a plant. The $\mathrm{N}$ element in NPK fertilizer has the function of preparing amino acids (proteins), nucleic acids, nucleotides, and chlorophyll in plants. The element $\mathrm{P}$ in the NPK fertilizer has a function as a storage and energy transfer. The $\mathrm{K}$ element in the NPK fertilizer serves as an enzyme activator, and assists in the transport of assimilated results from the leaf to the plant tissue (Jayaweera and Mikkelsen

1991).

Table (5): Interaction effects of NPK and sea force on some vegetative growth and flower characteristics of Calendula officinalis.

\begin{tabular}{cccccc}
\hline $\begin{array}{c}\text { NPK } \\
\left(\mathbf{g} \cdot \mathbf{k g}^{-1}\right)\end{array}$ & $\begin{array}{c}\text { Sea force } \\
\left(\mathbf{m g} \cdot \mathbf{L}^{-1}\right)\end{array}$ & $\begin{array}{c}\text { plant height } \\
\mathbf{( c m})\end{array}$ & $\begin{array}{c}\text { Number of } \\
\text { leaves. } \\
\text { plant }^{-1}\end{array}$ & $\begin{array}{c}\text { Number of } \\
\text { flowers. } \\
\text { plant }^{-1}\end{array}$ & $\begin{array}{c}\text { Flower } \\
\text { diameter } \\
(\mathbf{c m})\end{array}$ \\
\hline 0 & 0 & 49.74 & 177.88 & 14.50 & 4.83 \\
\cline { 2 - 5 } & 1 & 58.01 & 182.50 & 17.13 & 4.31 \\
\hline & 2 & 60.56 & 186.75 & 14.85 & 5.20 \\
\hline 0.25 & 3 & 56.65 & 118.38 & 11.75 & 4.48 \\
\hline & 0 & 53.63 & 104.25 & 7.63 & 4.76 \\
\hline & 1 & 52.54 & 112.50 & 9.70 & 4.68 \\
\hline & 2 & 46.41 & 95.50 & 5.63 & 4.32 \\
\hline 0.50 & 3 & 44.81 & 75.00 & 5.75 & 3.53 \\
\hline & 0 & 59.23 & 219.25 & 19.75 & 4.98 \\
\hline & 1 & 69.40 & 160.20 & 18.63 & 4.85 \\
\hline
\end{tabular}




\begin{tabular}{lccccc}
\hline \multirow{3}{*}{0.75} & 2 & 59.75 & 203.75 & 19.38 & 4.14 \\
\cline { 2 - 6 } & 3 & 62.43 & 200.63 & 18.95 & 4.55 \\
\cline { 2 - 6 } & 0 & 68.79 & 222.38 & 19.75 & 4.44 \\
\cline { 2 - 6 } & 1 & 65.00 & 216.13 & 20.38 & 4.53 \\
\cline { 2 - 6 } & 2 & 59.16 & 179.88 & 14.63 & 4.74 \\
\cline { 2 - 6 } & 3 & 62.63 & 164.13 & 16.25 & 4.48 \\
\hline
\end{tabular}

\subsection{Total flavonoid content estimation}

Different types of fertilizers have its advantages and disadvantages, as every type of plant species has its nutritional requirements (Naguib, 2011). The application of fertilizer affects the total flavonoid content of leaves and flowers of Calendula officinalis, the results in (figure 1) showed that total flavonoid content in the leaves is directly proportional to the increasing in NPK concentrations and the greatest effect in both leaves and flowers was recorded at the highest treated concentration $\left(0.75 \mathrm{~g} . \mathrm{kg}^{-1}\right)$ of NPK. The increasing of sea force concentration as shown in (figure 2) was not proportional to total flavonoid content in both leaves and flowers, and the highest amounts were estimated in leaves and flowers treated with sea force 3 and $2 \mathrm{mg}$. $\mathrm{L}^{-1}$ respectively.

The results of interaction treatments in (table 6) showed that using different combined concentrations of NPK and sea force is effecting on the amount of total flavonoid content in both leaves and flowers, the best interaction treatment concentration for NPK and sea force for leaves and flowers were recorded as $\left(0.25 \mathrm{g.} \mathrm{kg}^{-1}\right.$ and 3 $\left.\mathrm{mg} . \mathrm{L}^{-1}\right)$ and $\left(0.75 \mathrm{~g} . \mathrm{kg}^{-1}\right.$ and $\left.3 \mathrm{mg} . \mathrm{L}^{-1}\right)$ that resulted in total flavonoid content of $(21.320 \pm$ $0.010 \mathrm{mg} \cdot \mathrm{g}^{-1}$ and $\left.21.915 \pm 0.031 \mathrm{mg} \cdot \mathrm{g}^{-1}\right)$ respectively. Flowers produced higher amounts of total flavonoid content than leaves in most of the evaluated treatments.

Paim et al. (2010) recorded that the NPK treatment of Calendula officinalis raised the quantity of total flavonoids by around $10 \%$ when compared to organic fertilizer treatment, while Heimler et al (2017) found that soil nitrogen affects flavonoids content. The plant active principle of interest reflects specific adaptations to adverse conditions or to defense mechanisms, and such pathways may be stimulated by exposure of the plant to a nutrient-rich environment (Paim et al., 2010). The adoption of cultivation treatments, as well as fertilisers, is an indication that the species can produce greater quantities of active principles, considering that many nutrients contained in the fertiliser are found to be involved in secondary metabolic pathways (Taiz and Zeiger,

2002).

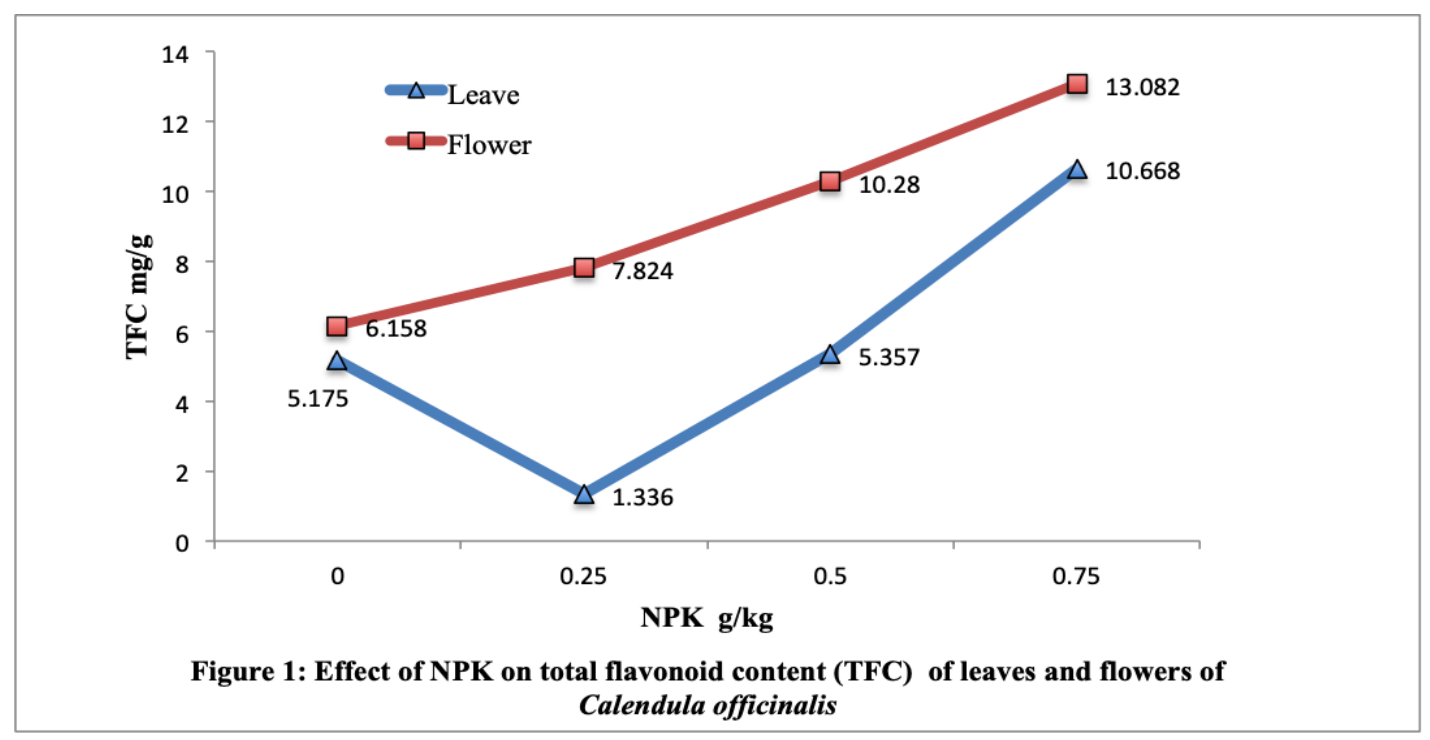




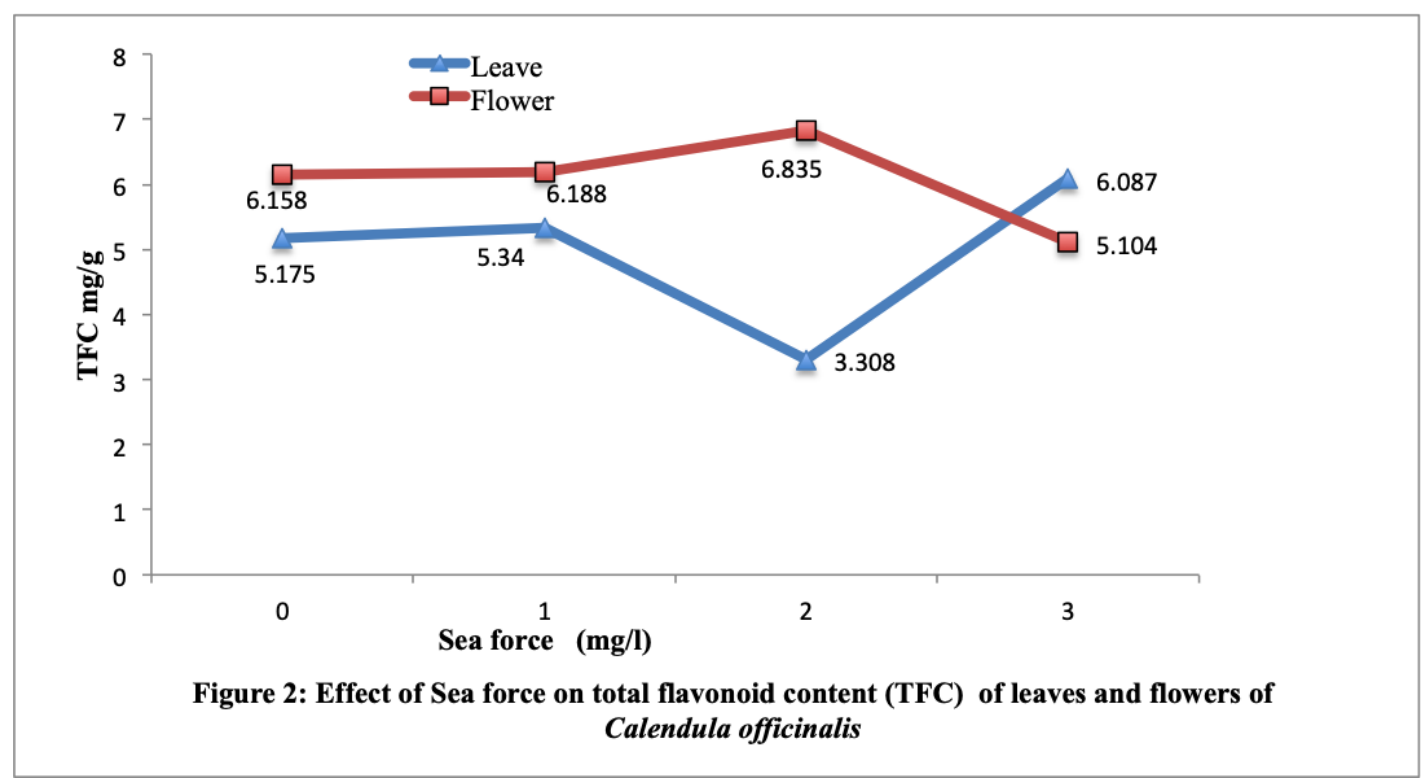

Table (6): Effect of interaction of NPK and sea force on total flavonoid content of leaves and flowers of Calendula officinalis.

\begin{tabular}{|c|c|c|c|}
\hline \multicolumn{2}{|c|}{ Treatments } & \multicolumn{2}{|c|}{ Total flavonoid content $(\mathrm{mg} / \mathrm{g})$} \\
\hline $\begin{array}{l}\text { NPK } \\
\left(\text { g.kg }{ }^{-1}\right)\end{array}$ & $\begin{array}{c}\text { Sea force } \\
\left(m g . L^{-1}\right)\end{array}$ & Leaves * & Flowers * \\
\hline \multirow{4}{*}{0} & 0 & $5.175 \pm 0.054$ & $6.158 \pm 0.057$ \\
\hline & 1 & $5.340 \pm 0.061$ & $6.188 \pm 0.031$ \\
\hline & 2 & $3.308 \pm 0.017$ & $6.835 \pm 0.020$ \\
\hline & 3 & $6.087 \pm 0.037$ & $5.104 \pm 0.010$ \\
\hline \multirow{4}{*}{0.25} & 0 & $1.336 \pm 0.027$ & $7.824 \pm 0.044$ \\
\hline & 1 & $4.003 \pm 0.027$ & $10.074 \pm 0.076$ \\
\hline & 2 & $10.839 \pm 0.037$ & $11.104 \pm 0.076$ \\
\hline & 3 & $21.320 \pm 0.010$ & $10.951 \pm 0.076$ \\
\hline \multirow{4}{*}{0.50} & 0 & $5.357 \pm 0.035$ & $10.280 \pm 0.010$ \\
\hline & 1 & $15.632 \pm 0.080$ & $13.442 \pm 0.040$ \\
\hline & 2 & $15.921 \pm 0.116$ & $7.848 \pm 0.091$ \\
\hline & 3 & $6.370 \pm 0.054$ & $5.811 \pm 0.020$ \\
\hline \multirow{4}{*}{0.75} & 0 & $10.668 \pm 0.020$ & $13.082 \pm 0.132$ \\
\hline & 1 & $12.470 \pm 0.057$ & $13.901 \pm 0.020$ \\
\hline & 2 & $10.244 \pm 0.057$ & $12.034 \pm 0.046$ \\
\hline & 3 & $6.476 \pm 0.037$ & $21.915 \pm 0.071$ \\
\hline
\end{tabular}

*Values are mean $\pm \mathrm{SD}, \mathrm{n}=3$

\section{CONCLUSIONS}

1. This study suggests that NPK and sea force fertilizers can be used to get better plant length, number of leaves and flowers in addition to increase the production of flavonoids from Calendula officinalis.

2. It can be seen that the studied vegetative growth and flower properties exhibited significant differences as a result of the treatments tested generally in the highest levels of NPK and the lowest sea force extract level.

3. Total flavonoid content was increased in both leaves and flowers with highest level of NPK foliar feeding. In otherwise stated sea force fertilizer had lower effect on it. Flowers produced higher amounts of total flavonoid content than leaves in most of the evaluated treatments. 


\section{REFERENCES}

- ABDULRAHMAN, A. S. (2013) Effect of Foliar Spray of Ascorbic Acid, Zinc, Seaweed Extracts and Biofertilizer (EM1) on Growth of Almonds (Prunus amygdalus) Seedling. International Journal of Pure and Applied Sciences and Technology1, 7(2): 62-71.

- AHMED, R., HUSSAIN, M.J. , AHMED, S. , KARIM, M.R. and SIDDIKY, M.A. (2017) Effect of Nitrogen, Phosphorus and Potassium Fertilizers on Yield and Yield Attributes of Marigold (Tagetes patula L.). The Agriculturists A Scientific Journal of Krishi Foundation, 15(1):101-109.

- CALISKAN, O. and KURT, D. (2018) Flower yields of pot marigold (Calendula officinalis L.) plants as effected by flowering durations and number of harvests. Journal of Medicinal Plants Studies, 6 (6): 159-161.

- CRISTIANE P. V., LAGE, C. L. S. and KUSTER, R. M. (2009) Flavonoid extraction from Alpinia zerumbet (Pers.) Burtt et Smith leaves using different techniques and solvents. Ecl. Quím., São Paulo, 34(1): 19-24.

- GOLESTANI, M., DOLATKHAHI, A. and KAZEMI, F. (2013) Effect of Planting Dates on Flowering Period of Calendula officinalis, Bellis perennis and Viola sp. Advanced Crop Science, 3(8): 563-567.

- HASAN, A. E., BHIAH, K. M. and ALZURFY, M. A. H. (2014) The impact of peat moss and sheep manure compost extracts on marigold (Calendula officinalis L.) growth and flowering. Journal of Organic Systems 9(2):5662.

- HASHEMABADI, D., MOSTOFIPOUR, A.A., BERIMAVANDI, A.R., KAVIANI, B. and ZARCHINI, M. (2012) Improvement of the Yield and Essential Oils Quantitative in Calendula (Calendula officinalis L.) by Using Different Planting Arrangement and Potassium Fertilizer. Journal of Ornamental and Horticultural Plants, 2 (3): 147-154.

- HEIMLER, D., A. ROMANI, AND F. IERI (2017) Plant polyphenol content, soil fertilization and agricultural management: a review. Eur Food Res Technol 243:1107-1115.

- HOSSAIN, M. A., AL-RAQMI, K. A. S., ALMIJIZY, Z. H., WELI, A. M. and AL- RIYAMI, Q. (2013) Study of total phenol, flavonoids contents and phytochemical screening of various leaves crude extracts of locally grown Thymus vulgaris. Asian Pac J Trop Biomed, 3(9): 705710.
- JANMOHAMMADI, M., SUFI-MAHMOUDI, Z., AHADNEZHAD, A., YOUSEFZADEH, S., and SABAGHNIA, N. (2014) Influence of chemical and organic fertilizer on growth, yield and essential oil of dragonhead (Dracocephalum moldavica L.) plant. Acta agriculturae Slovenica, 103 (1): $73-81$.

- JAYAWEERA, G.R. and MIKKELSEN, D.S. (1991) Assessment of ammonia volatilization from flooded soil systems. Advances in Agronomy 45:303-353.

- JENSEN, E. (2004) Seaweed- Fact or fancy: From the organic broad caster. Moses the Midwest Organic and Sustainable Education, From the Broad Caster, 12(3): 164-170.

- MARTA, A. E., JITĂREANU, C. D. AND SLABU, C. (2012) The effect of mineral fertilization on the pigment content in marigold (callendula officinalis L.). The University of Agricultural Sciences and Veterinary Medicine Iasi. Lucrări Ştiinţifice, seria Agronomie(51).

- MOHAMMAD, S. M. and, KASHANI, H. H. (2012) Pot marigold (Calendula officinalis) medicinal usage and cultivation. Scientific Research and Essays 7(14):1468-1472. (Review)

- MULEY, B. P., KHADABADI, S. S., and BANARASE, N. B. (2009) Phytochemical Constituents and Pharmacological Activities of Calendula officinalis Linn (Asteraceae). Tropical Journal of Pharmaceutical Research, 8 (5): 455465. (Review).

- NAGUIB, N. Y. M.(2011). Organic Vs Chemical Fertilization of Medicinal Plants: A Concise Review of researches. Advances in Environmental Biology, 5(2): 394-400.

- NAGUIB, N. Y. M. (2011) Organic Vs chemical fertilization of medicinal plants: a concise review of researches. Advances in Environmental Biology, 5(2): 394-400.

- PAIM , L. F., ALVES, N., FONTANA, M., WINCKLER, M., GRANDO, A. A., MUNERON, T. L. and JÚNIOR, W. A. (2010) Assessment of plant development, morphology and flavonoid content in different cultivation treatments of Calendula officinalis L., Asteraceae. Brazilian Journal of Pharmacognosy20: 974-980.

- PRIYADARSHINI, A., PALAI, S. K. and M. R. NATH (2018) Effect of source of nitrogen on growth and yield of African marigold (Tagetes erecta L.). The Pharma Innovation Journal, 7(7): 917-921.

- RAFIEE H., MEHRAFARIN, A., BADI H. N., JARI JARI, S. K., QAVAMI, N. AND QADERI, A. (2014) Role of Bio-stimulators on Seed 
Germination and seedling nutrient content of Pot Marigold (Calendula officinalis L.). Annals of Biological Research 3 (12): 5478-5485 (http://scholarsresearchlibrary.com/archive.html)

- RAJPUT, A. S. (2015) Effect of Nitrogen and Phosphorus on Growth and Flowering of French marigold (Tagetes patula L.) cv. Pusa Arpita under Malwa Region of Madhya Pradesh. M.Sc thesis, Floriculture and Landscape Architecture, College of Horticulture, Mandsaur,

-SAJID, M. and AMIN, N. (2014) Effect of various combinations of nitrogen, phosphorus and potash on enhancing the flowering time in Chrysanthemum (Chrysanthemum morifolium). International J. of Biosciences 4(10):99-108.

- SAS (2005). Statistical analysis system Institute, Cary NC, USA.

- TAIZ, L. and ZEIGER, E. (2002) Plant Physiology. $3^{\text {rd }}$ edition. Senaure Associates , Inc.

$-$ publisher. USA. p. 515.

- TUHY, Ł., CHOWAŃSKA, J. and CHOJNACKA, K. (2013) Seaweed extracts as biostimulants of plant growth. Institute of Inorganic Technology and Mineral Fertilizers, Faculty of Chemistry, Wroclaw University of Technology, Poland, CHEMIK, 67(7):636-641. (Review)

- VERMA S. K., ANGADI, S. G., PATIL,V. S., MOKASHI, A. N., MATHAD, J C. and MUMMIGATTI, U.V. ( 2011) Growth, yield and quality of chrysanthemum (Chrysanthemum morifolium Ramat.) Cv. Raja as influenced by integrated nutrient management. Karnataka Journal of Agricultural Sciences 24(5), 681-683.

كاريكَرى NPK و يالاوتهى Sea force له سهر خهسله تهكانى گهشه و رِيّزَى كوّى فلاقوّنوّيدهكان لهناو

\section{Calendula officinalis}

يوخته

مارى كولد Calendula officinalis به رووهكيّكى يزيشكى و جوانكارى گرنگ دادهندرئ. ئهم تويّزينهوه لهناو خانووى دارى سيّبهركيلكَه كردهرهشه سهر به كوليّزى كشتوكالى زانكوّى سهلاحهددين ئهنجامدرا،

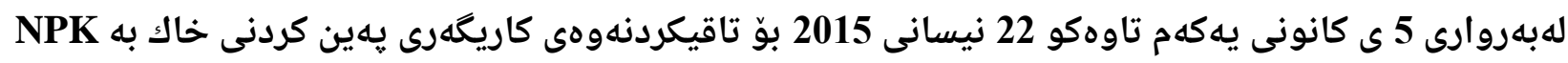

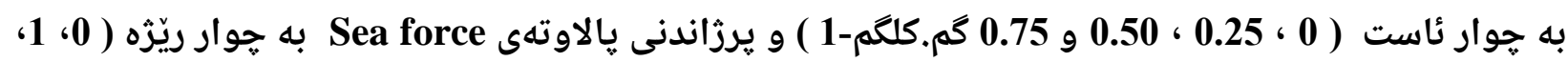

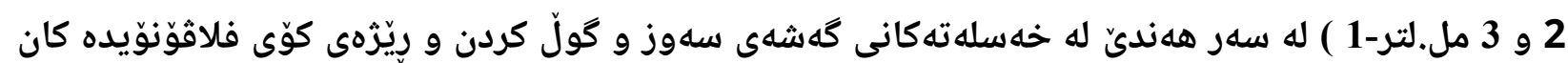

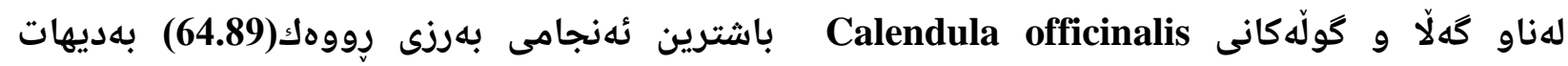

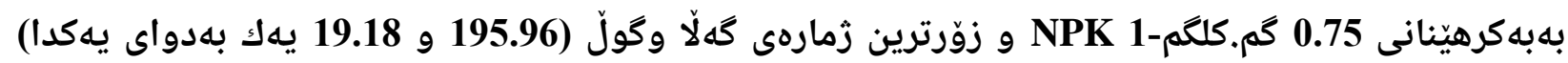

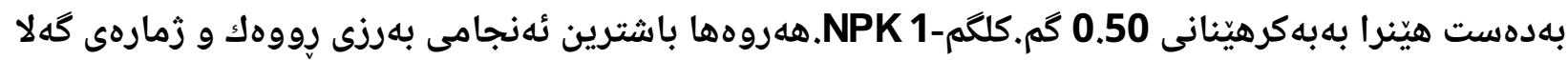
و كولّ بهدهست هينرا به يِّزاندنى 1 مل.لتر-1 يالاوتهى Sea force. له ئهنجامى كارليّكى نيّوان 0.50

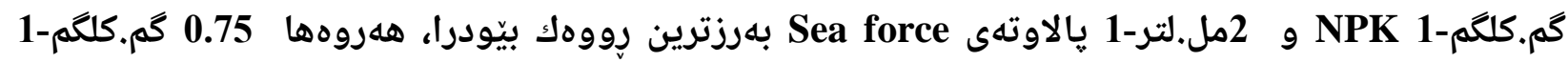

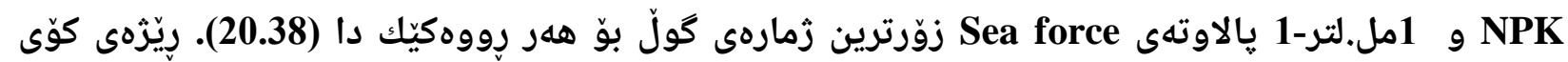

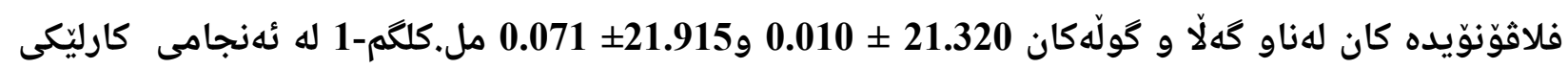

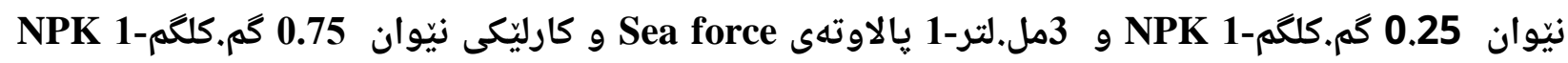

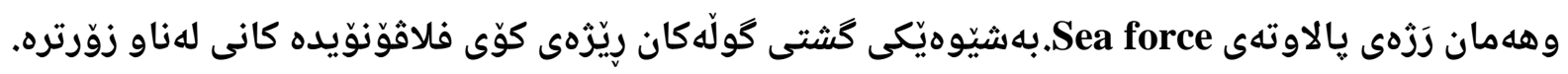

